\title{
HUBUNGAN PENGETAHUAN DAN MINAT PEKERJA SEKS KOMERSIAL DALAM PENGGUNAAN KONDOM WANITA DI LOKALISASI BOLODEWO KECAMATAN WATES KABUPATEN KEDIRI.
}

Susiani Endarwati, S.ST, M.Kes ${ }^{1}$, Dwi Friska Dyan Putri ${ }^{2}$

Akademi Kebidanan Dharma Husada Kediri Jawa Timur

\begin{abstract}
ABSTRAK
Kondom wanita merupakan alat yang digunakan selama hubungan seksual. Banyak wanita terjerumus ke dalam bisnis prostitusi, tetapi semakin banyaknya bisnis tersebut tidak dibarengi dengan kesadaran pelaku untuk menjaga dirinya dari ancaman penyakit menular seksual. Tujuan dalam penelitian ini adalah untuk mengetahui hubungan pengetahuan dan minat pekerja seks komersial dalam penggunaan kondom wanita di Lokalisasi Bolodewo Kec. Wates Kab.Kediri.

Desain yang digunakan adalah studi korelasi dengan pendekatan cross sectional. Populasi dalam penelitian ini adalah semua pekerja seks komersial sebanyak 60 orang. Pengambilan sampel menggunakan teknik total sampling. Variabel dalam penelitian ini yaitu variabel independen adalah pengetahuan pekerja seks komersial tentang kondom wanita dan variabel dependen adalah minat pekerja seks komersial dalam penggunaan kondom wanita. Pengumpulan data menggunakan kuesioner. Pengolahan data meliputi Editing, Coding, Scoring, Tabulating, dianalisa menggunakan uji Spearman Rank.

Hasil dari penelitian diperoleh bahwa pengetahuan pekerja seks komersial tentang kondom waanita dalam katekori cukup $(41,7 \%)$, dan minat pekerja seks komersial dalam penggunaan kondom wanita dalam kategori tinggi $(61,7 \%)$. Dari data tersebut dilakukan uji statistik dengan hasil sig $(\mathrm{p})=0,000$ dan $\mathrm{a}=0,05$ jadi $\mathrm{H}_{0}$ ditolak dan $\mathrm{H}_{1}$ diterima.

Berdasarkan hasil penelitian dapat disimpulkan bahwa ada hubungan pengetahuan dan minat pekerja seks komersial dalam penggunaan kondom wanita. Diharapkan pekerja seks komersial memakai kondom wanita setiap melakukan hubungan seksual, untuk mencegah kehamilan dan penyakit menular seksual. Peran tenaga kesehatan diperlukan untuk memotivasi pekerja seks komersial dalam penggunaan kondom wanita.
\end{abstract}

Kata Kunci : Pengetahuan, minat, pekerja seks komersial, kondom wanita 


\section{PENDAHULUAN}

Kondom perempuan merupakan alat kontrasepsi yang berbentuk seperti balon atau kantong dan terbuat dari lateks tipis atau polyurethane atau nitril dan dipasang dengan cara memasukkan ke dalam vagina perempuan (Uliyah, $2010: 36$ ).

Meningkatnya kebutuhan setiap individu,menjadi salah satu alasan seorang wanita mengambil jalan pintas untuk memenuhi kebutuhan tersebut salah satunya menjadi seorang pekerja seks komersial (PSK). Banyak wanita terjerumus ke dalam bisnis tersebut, dengan berbagai alasan dan latar belakang. Tetapi semakin banyaknya bisnis tersebut tidak dibarengi dengan kesadaran pelaku untuk menjaga dirinya dari ancaman penyakit menular seksual seperti HIV/AIDS. HIV/AIDS dapat dicegah dengan menggunakan kondom secara konsisten.

Salah satu penyebab tipisnya pasar kondom di Indonesia adalah rendahnya penerimaan sebagai masyarakat terhadap kondom sebagai alat kontrasepsi. Ada anggapan bahwa pemakai kondom selalu identik dengan hubungan seksual di luar nikah (Tratnasasi, 2007).

Pada tahun 2012, pengguna kondom wanita masih sangat minim. Dari 16.000 kondom yang di sebar sejak 2009, tercatat baru sekitar 1.000 kondom yang digunakan (Sindonews, 2012). Pada tahun 2014 pengguna kondom di Indonesia sekitar 7,07\%. Sedangkan di Jawa Timur sekitar 2,66\% (BkkbN, 2014).

Berdasarkan studi pendahuluan di Lokalisasi Bolodewo Kecamatan Wates Kabupaten Kediri pada tanggal 18 Maret 2015 dari 10 orang yang diwawancarai 4 orang $(40 \%)$ mengatakan mengerti tentang kondom wanita dan 6 orang $(60 \%)$ sisanya belum mengerti tentang kondom wanita. Dari 4 orang yang mengerti, mereka pernah memakai kondom wanita tetapi sekarang tidak memakai karena penggunaan kondom wanita di anggap sulit.

\section{METODE}

Research design atau desain penelitian adalah rencana atau struktur dan strategi penelitian yang disusun demikian rupa agar dapat memperoleh jawaban mengenai permasalahan penelitian dan juga untuk mengontrol varians. Rancangan penelitian yang digunakan dalam penelitian ini yaitu studi korelasi (correlation study) dengan menggunakan pendekatan penelitian secara cross sectional. Pada penelitian ini populasinya adalah semua PSK di Lokalisasi Bolodewo Kecamatan Wates Kabupaten Kediri sebanyak 60 responden.

Teknik sampling yang digunakan adalah total sampling atau sampling jenuh. Variabel pada penelitian ini adalah pengetahuan PSK tentang penggunaan kondom wanita dan minat PSK dalam penggunaan kondom wanita

Instrumen dalam penelitian ini menggunakan kuesioner dengan jumlah 31 item peryataan tentang minat. Penelitian ini dilaksanakan di Lokalisasi Bolodewo Kecamatan Wates Kabupaten Kediri pada tanggal 9 Mei 2015.

Hasilpenelitiankuesioner yang telahdikumpukanlaludiolahdengancarae diting, coding, scoring, dantabulatinguntukpengujianhip otesa.

Skor yang didapatkemudiandijumlahdantentukan ranking setelah itu dimasukkandalamrumus:

$$
r_{s} \text { hitung }=1-\frac{6 \sum d^{2}}{n\left(n^{2}-1\right)}
$$

Keterangan:

$\mathrm{r}_{\mathrm{s}} \quad$ nilai korelasi Spearman Rank

$\mathrm{d}^{2} \quad$ : selisih setiap pasangan Rank

$\mathrm{n}$ : jumlah pasangan Rank untuk Spearma 
HASIL

Data Khusus

a. Pengetahuan Responden tentang Kondom Wanita

Tabel IV.5 Distribusi Frekuensi Pengetahuan Responden tentang Kondom Wanita di Lokalisasi Bolodewo Kecamatan Wates Kabupaten Kediri pada tanggal 4-16 Mei 2015

\begin{tabular}{|c|l|c|c|}
\hline No & Pengetahuan & Frekuensi & Presentasi (\%) \\
\hline 1 & Baik & 23 & 38,3 \\
\hline 2 & Cukup & 25 & 41,7 \\
\hline 3 & Kurang & 12 & 20 \\
\hline \multicolumn{2}{|c|}{ Total } & $\mathbf{6 0}$ & $\mathbf{1 0 0}$ \\
\hline
\end{tabular}

Berdasarkan tabel IV.5 menunjukkan bahwa dari 60 responden yang diteliti mayoritas responden memiliki pengetahuan cukup sejumlah 25 responden $(41,7 \%)$ dan minoritas responden memiliki pengetahuan kurang sejumlah 12 responden $(20 \%)$.

b. Minat Responden dalam Penggunaan Kondom Wanita

Tabel IV.6 Distribusi Frekuensi Minat Responden dalam Penggunaan Kondom Wanita di Lokalisasi Bolodewo Kecamatan Wates Kabupaten Kediri pada tanggal 4-16 Mei 2015

\begin{tabular}{|c|c|c|c|}
\hline No & Minat & Frekuensi & Presentasi (\%) \\
\hline 1 & B Tinggi & 37 & 61,7 \\
\hline 2 & Sedang & 23 & 38,3 \\
\hline 3 & Rendah & 0 & 0 \\
\hline \multicolumn{2}{|c|}{ Total } & $\mathbf{6 0}$ & $\mathbf{1 0 0}$ \\
\hline
\end{tabular}

E

Berdasarkan tabel IV.6 menunjukkan bahwa dari 60 responden yang diteliti mayoritas responden memiliki minat tinggi dalam penggunaan kondom wanita sejumlah 37 responden $(61,7 \%)$ dan minoritas responden memiliki minat sedang dalam penggunaan kondom wanita sejumlah 23 responden $(38,3 \%)$.

c. Hubungan Pengetahuan dan Minat Responden dalam Penggunaan Kondom

Tabel IV.7 Tabulasi Silang Pengetahuan dan Minat Responden dalam Penggunaan Kondom Wanita di Lokalisasi Bolodewo Kecamatan Wates Kabupaten Kediri pada tanggal 4-16 Mei 2015

\begin{tabular}{|c|c|c|c|c|c|c|c|c|}
\hline \multirow{2}{*}{ Pengetahuan } & \multicolumn{2}{|c|}{ Tinggi } & \multicolumn{2}{|c|}{ Sedang } & \multicolumn{2}{|c|}{ Rendah } & \multicolumn{2}{|c|}{ Jumlah } \\
\hline & $\mathrm{N}$ & $\%$ & $\mathrm{~N}$ & $\%$ & $\mathrm{~N}$ & $\%$ & $\mathrm{~N}$ & $\%$ \\
\hline B Baik & 22 & 26,7 & 1 & $1,6 \%$ & 0 & 0 & 23 & $\mathbf{3 8 , 3}$ \\
\hline Cukup & 13 & 21,7 & 12 & 20,0 & 0 & 0 & 25 & 41,7 \\
\hline Kurang & 2 & 3,3 & 10 & 16,7 & 0 & 0 & 12 & 20,0 \\
\hline Jumlah & 37 & 61,7 & 23 & 38,3 & $\mathbf{0}$ & $\mathbf{0}$ & 60 & 100 \\
\hline $\begin{array}{l}\text { Uji Statistik : Spea } \\
\text { Menunjukkan nilai }\end{array}$ & $n R$ & 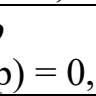 & & & & & & \\
\hline
\end{tabular}

arkan tabel IV.7 dapat dijelaskan bahwa jumlah yang terbesar adalah pengetahauan 
baik dan minat tinggi dengan 22 responden (26,7\%), dari hasul uji Spearman Rho dengan bantuan SPSS didapat hasil akhir sig $(\mathrm{p})=0,000$ dan $a=0,05$ jadi $\mathrm{p}<a$ maka $\mathrm{H}_{0}$ ditolak dan $\mathrm{H}_{1}$ diterima artinya ada hubungan pengetahuan dan minat pekerja seks komersial dalam penggunaan kondom wanita.

\section{DISKUSI}

1. Pengetahuan Pekerja Seks Komersial tentang Kondom Wanita

Dari hasil penelitian menunjukkan dari 60 responden terdapat 12 responden $(20 \%)$ memiliki pengetahuan kurang, 25 responden $(41,7 \%)$ memiliki pengetahuan cukup dan 23 responden $(38,3 \%)$ memiliki pengetahuan baik.Salah satu faktor yang mempengaruhi adalah tingkat pendidikan, hasil penelitian didapatkan 32 responden $(36,7 \%)$ berpendidikan SD.

Pendidikan berarti bimbingan yang diberikan seseorang terhadap perkembangan orang lain menuju ke arah cita-cita tertentu yang menentukan manusia untuk berbuat dan mengisi kehidupan untuk berbuat dan mengisi kehidupan untuk mencapai keselamatan dan kebahagiaan. Pendidikan diperlukan untuk mendapat informasi misalnya hal-hal yang menunjang kesehatan sehingga dapat meningkatkan kualitas hidup (Wawan, 2010 : 16).

Informasi yang diperoleh individu mempengaruhi tingkat pengetahuan. Pengetahuan responden tidak hanya didapat dari pendidikan formal, tetapi dapat juga diperoleh dari pendidikan non formal. Meskipun responden memiliki pendidikan formal yang kurang tetapi mereka mendapatkan pendidikan non formal melalui penyuluhan yang sering diadakan oleh pihak setempat.

2. Minat Pekerja Seks Komersial dalam Penggunaan Kondom Wanita

Berdasarkan hasil penelitian didapatkan bahwa minat pekerja seks komersial dalam penggunaan kondom wanita dengan kategori tinggi sejumlah 37 responden $(61,7 \%)$, dan kategori sedang 23 responden $(38,3 \%)$.

Minat seseorang di pengaruhi oleh beberapa indikator yaitu, ketertarikan, perhatian, motivasi, dan pengetahuan.

3. Hubungan Pengetahuan dan Minat Pekerja Seks Komersial dalam Penggunaan Kondom Wanita

Berdasarkan hasil penelitian yang telah dilakukan peneliti mendapatkan hasil bahwa hubungan pengetahuan dan minat pekerja seks komersial dalam penggunaan kondom wanita di Lokalisasi Bolodewo Kecamatan Wates Kabupaten Kediri. Dapat dilihat dari hasil tabulasi silang, Pekerja seks Komersial yang memiliki pengetahuan baik dan memiliki minat tinggi sebanyak 22 responden (26,7\%). Pekerja seks komersial yang memiliki pengetahuan baik dan memiliki minat sedang sebanyak 1 responden (1,6\%). Pekerja seks komersial yang memiliki pengetahuan cukup dan memiliki minat tinggi sebanyak 13 responden (21,7\%). Pekerja seks komersial yang memiliki pengetahuan cukup dan memiliki minat sedang sebanyak 12 responden (20\%). Pekerja seks komersial yang memiliki pengetahuan kurang dan yang memiliki minat tinggi sebanyak 2 responden $(3,3 \%)$. Pekerja seks komersial yang memiliki pengetahuan kurang dan yang memiliki minat sedang sebanyak 10 responden $(16,7 \%)$. 


\section{SIMPULAN}

1. Pengetahuan Pekerja Seks Komersial tentang Kondom Wanita di Loakalisasi Bolodewo Kecamatan Wates Kabupaten Kediri termasuk dalam kriteria cukup sejumlah 25 responden $(41,7 \%)$.

2. Minat Pekerja Seks Komersial dalam Penggunaan Kondom Wanita di Lokalisasi Bolodewo Kecamatan Wates Kabupaten Kediri termasuk dalam kreteria tinggi sejumlah 37 responden $(61,7 \%)$.

3. Hasil analisa dari uji Spearman Rho dengan hasil akhir sig $(\mathrm{p})=0,000$ dan $\alpha=0,05$ jadi $\mathrm{p}<\alpha$ maka $\mathrm{H}_{0}$ ditolak dan $\mathrm{H}_{1}$ diterima artinya ada Hubungan Pengetahuan dan Minat Pekerja Seks Komersial dalam Penggunaan Kondom Wanita di Lokalisasi Bolodewo Kecamatan Wates Kabupaten Kediri. 


\section{DAFTAR PUSTAKA}

Ahamadi, Abu. 2009. Psikologi Umum. Jakarta: PT Rineka Cipta.

Arikunto, Suharsimi. 2010. Prosedur Penelitian Suatu Pendekatan Praktik. Jakarta: PT Rineka Cipta.

Dewi \& Wawan. 2010. Teori dan Pengukuran, Sikap, dan Perilaku Manusia. Yogyakarta: Pustaka Belajar.

Everett, Suzane. 2007. Kontrasepsi dan Kesehatan Seksual Reproduktif. Jakarta: EGC.

Handayani, Sri. 2010. Buku Ajar Pelayanan Keluarga Berencana. Yogyakarta: Pustaka Rihama.

Hidayat, Aziz Alimul A. 2005. Pengantar Ilmu Keperawatan Anak 1. Jakarta: Salemba Medika.

2007.

Riset Keperawatan dan Teknik Penulisan Ilmiah. Jakarta: Salemba Medika.

2009.

Metode Penelitian Keperawatan dan

Teknik Analisis Data. Jakarta: Salemba Medika.

Irianto, Koes. 2014. Pelayana Keluarga

Berencana. Bandung: Alfabeta.

Kumalasari, Intan. Iwan Andhyantoro. 2014. Kesehatan Reproduksi untuk Mahasiswa Kebidanan dan Keperawatan. Jakarta: Salemba Medika.

Machfoedz, Ircham. 2010. Metodologi

Penelitian. Yogyakarta: Fitramaya.

Manuaba, Ida Bagus Gde Dkk. 2009. Memahami Kesehatan Reproduksi Wanita. Jakarta: EGC.

Mubarak, Wahid. 2011. Promosi Kesehatan Untuk Kebidanan. Jakarta: Salemba Medika.

Notoadmodjo, Soekidjo. 2005. Metodologi Penerapan Kesehatan. Jakarta : PT Rineka Cipta.

2010.

Metodologi Penerapan Kesehatan. Jakarta : PT Rineka Cipta.
Sugiono. 2010. Statistika untuk Penelitian. Bandung: Alfabeta. . 2011. Metodologi Penelitian Kuantitatif kualitatif dan $R \& D$. Bandung: Alfabeta

Sulistyawati, Ari. 2011. Pelayanan Keluarga Berencana. Jakarta: Salemba Medika.

Uliyah, Mar'atul. 2010. Awas KB! Panduan Aman dan Sehat Memilih Alat KB. Yogyakarta: Insania.

Anonimus. 2010. Konsep Minat . http://creasoft.wordpress.com/. Diakses tanggal 11 Maret 2015

Nurul Arifin. 2008. Tips Penting sebelum menggunakan Kondom.http://www.resep.web.id. Diakses tanggal 15 Maret 2015

Rizki, Faisal. 2014. Di Kediri, Ditemukan 615 Kasus HIV-AIDS. http://www.aktual.co/nusantara/. Diakses tanggal 11 Maret 2015.

Sindonews. 2012. Pengguna Kondom Wanita Minim. Diakses dari http:// economy.okezone.com/. Diakses 
